Marcin Wałdoch*

\title{
Postawy wobec instytucji państwa wśród Duszpasterstwa Ludzi Pracy \\ w analizach Służby Bezpieczeństwa PRL
}

\section{Attitudes towards state institutions among the Pastoral Care of the Working People in the analyzes of the Security Service of the People's Republic of Poland}

Stowa kluczowe: ruch społeczny, komunizm, Solidarnośc, statofobia, Kościót katolicki, Duszpasterstwo Ludzi Pracy

Keywords: social movement, communism, Solidarity, state-phobia, Catholic Church, Christian Work Ministry

Abstrakt: W prezentowanym artykule podjęto się charakterystyki Duszpasterstwa Ludzi Pracy $w$ ocenach SB. Wykonano analize dokumentów Służby Bezpieczeństwa oraz prac dyplomowych funkcjonariuszy SB, którzy koncentrowali się na Duszpasterstwie Ludzi Pracy, a szczególnie na zagrożeniu dla państwa i reżimu komunistycznego, ze strony DLP. W tym studium postawiono dwie hipotezy. Hipoteza byto przypuszczenie, że funkcjonariusze SB postrzegali aktywistów DLP $i$ tę organizacje jako istotne zagrożenie dla bezpieczeństwa państwa $i$ przypisywali temu środowisku postawy statofobiczne. Hipoteza pomocnicza było przypuszczenie, że środowisko DLP byto schronieniem dla bytych działaczy NSZZ „Solidarność" $i$ kontynuowało kierunki działalności zwiazzku, w ograniczonym zakresie, po jego delegalizacji pod sztandarami DLP.

Abstract: The issue of Christian Work Ministries (CWM) in Poland during the communist regime have so far been hardly explored. Empirical data collected in Archive of Institute of National Remembrance were analyzed, to show the perspective on CWM from Security Services (SB) point of view. In their eyes CWM were dangerous and threat for security of state and communism in Poland. The hypothesis of the survey was the assumption that

* ORCID ID: https://orcid.org/0000-0002-8778-1780; doktor nauk społecznych w zakresie nauk o polityce, adiunkt w Katedrze Polityki Bezpieczeństwa, Wydział Nauk o Polityce i Administracji Uniwersytet Kazimierza Wielkiego w Bydgoszczy. Email: waldoch@ukw.edu.pl. 
SB saw CWM and its activists as a source of threat for the state and were state-phobic. Auxiliary hypothesis was assumption that CWM was a shelter for former members of "Solidarity" and as a members of CWM they continued their activism, to a limited extent, known from "Solidarity".

\section{Wstęp}

Działalność Duszpasterstw Ludzi Pracy (DLP), prowadzona była w sposób sformalizowany, były to organizacje przykościelne, składające się z świeckich, którzy działali pod kuratelą duchownych Kościoła katolickiego. Jako datę powstania DLP wskazuje się 1973 r., a działalność DLP określić należy jako na wpół jawną. Zauważa się, że DLP zyskały znaczą popularność wśród społeczeństwa polskiego po delegalizacji NSZZ „Solidarność” i następnie po ustaniu stanu wojennego w 1983 r. Choć też w okresie stanu wojennego DLP działały, stanowiąc swoistą oazę dla osób poszukujących wsparcia. Nad działalnością DLP kuratelę sprawowali wyznaczeni przez biskupów ordynariuszy diecezji Kościoła katolickiego księża. Jednym z opiekunów DLP, dla średniego personelu medycznego w archidiecezji warszawskiej od 1979 r. był ks. Jerzy Popiełuszko (1947-1984). Pomimo sformalizowanej struktury i pieczy Kościoła katolickiego, DLP należy uznać za ruch społeczny, bowiem jego działalność była ukierunkowana na zmianę i ogniskowała się wokół wysoce abstrakcyjnych idei, a członkowie wykazywali się wysoką świadomością polityczną i współpracowali ze sobą. W swojej aktywności DLP określiło cele, którymi była walka o wolność, godność człowieka pracy, prawo pracy oraz prawa pracowników. Hierarchowie Kościoła katolickiego liczyli także, że poprzez DLP poprowadzą walkę ze społecznymi patologiami dręczącymi polskie społeczeństwo, z alkoholizmem oraz narkomanią. W ramach Episkopatu Polski to ks. kardynał Henryk Gulbinowicz był desygnowany do Komisji ds. Duszpasterstwa Ludzi Pracy, jego zastępcą był kardynał Franciszek Macharski, a sekretarzem ks. Benedykt Woźnicaํ. Duchowieństwo zauważyło po delegalizacji „Solidarności” próżnię, którą Kościół zdecydował się w jakiejś mierze wypełnić, pomimo tego, że nie miał ku temu wcześniejszych doświadczeń w Polsce. Działalność przykościelna miała umacniać duchowo i była swoistą formacją do życia społecznego poprzez

1 Archiwum Instytut Pamięci Narodowej (dalej: AIPN), sygn. IPN BU 001708/3565, D. Pęcak, Duszpasterstwo ludzi pracy na terenie województwa wałbrzyskiego w latach 1984-1987. Praca dyplomowa, Ministerstwo Spraw Wewnętrznych Wyższa Szkoła Oficerska im. F. Dzierżyńskiego, Legionowo 1989, s. 52. 
przekazywanie członkom DLP zasad katolickiej nauki społecznej. Oprócz walki ze zjawiskami patologicznymi DLP poszerzało wiedzę członków na tematy prawa pracy, o historii Polski i Kościoła oraz przekazywało wiedzę, która winna pomóc w rozpoznaniu sytuacji społeczno-politycznej oraz moralnej². DLP znalazło więc swoich oddanych duszpasterzy, pomimo tego, że opozycja polityczna w latach 1982-1983 była popierana przez około 5-10\% księży i niewielu biskupów Kościoła katolickiego. Fakt zabójstwa dokonanego na ks. J. Popiełuszce w 1984 r. i wcześniejsze wprowadzenie stanu wojennego 13 grudnia 1981 r. zaciążyły wydatnie na przyjęciu przez Kościół katolicki postawy wrogiej reżimowi komunistycznemu, która była jedynie kamuflowana wolą podtrzymania dialogu z ekipą Wojciecha Jaruzelskiego $^{3}$. Kościół katolicki wyraził swój zdecydowany sprzeciw wobec stanu wojennego ${ }^{4}$. Z kolei władze komunistyczne zaostrzyły kurs polityki wobec Kościoła w latach 1982-1986. Wprowadzając od 1986 r. w relacjach państwo-kościół odwilż w obliczu zmian systemowych, polskim komunistom zależało na dobrych relacjach z Kościołem, miało to ułatwić wyjście PRL z izolacji na arenie międzynarodowej ${ }^{5}$.

\section{Stan badań}

DLP pozostaje jedną z najsłabiej rozpoznanych i zbadanych organizacji życia społecznego okresu PRL, a na temat jej funkcjonowania istnieje bardzo skromna literatura, i jest ona z zakresu socjologii religii ${ }^{6}$. Można uznać, że w świetle braku monograficznego ujęcia fenomenu jakim było DLP, istnieje luka poznawcza, którą w ograniczonej mierze ma wypełnić to studium. Analizowane materiały stanowią podstawę do wyciagania wniosków o dużej wadze poznawczej, gdyż ich twórcy bazowali przede wszystkim na materiałach operacyjnych służb bezpieczeństwa PRL. W literaturze przedmiotu dostrzega się brak uwagi dla działalności DLP i czego dowodzi niniejsze studium, zupełne pomijanie znaczenia tej organizacji dla przetrwania opozycji demokratycznej w sytuacji politycznej powstałej w Polsce po 13 grudnia $1981 \mathrm{r}$.

2 «Народное слово» от 9 сентября 2017 года № 180 (6844).

3 M. Wałdoch, Duszpasterstwo Ludzi Pracy w Chojnicach: geneza, idee, struktura, ludzie i działalność polityczna (1982-1989), «Zeszyty Chojnickie» 2017, nr 33, s. 24-25.

4 P. Kowal, Koniec systemu wtadzy. Polityka ekipy gen. Wojciecha Jaruzelskiego w latach 1986-1989, Warszawa 2015, s. 213-214.

5 R. Łatka, Episkopat Polski wobec stosunków państwo-kościót i rzeczywistości społeczno-politycznej PRL 1970-1989, Warszawa 2019, s. 490-491.

6 Zob. P. Boryszewski, Duszpasterstwa Ludzi Pracy w latach 1973-1990, Warszawa 1995. 


\section{Materiały źródłowe}

Badania zostały wykonane jako analiza dokumentów Służby Bezpieczeństwa (SB) dotyczących DLP, które zgromadzone są w Archiwum Instytutu Pamięci Narodowej. W'́ród tych dokumentów, które poddano analizie są Sprawy Operacyjnego Rozpracowywania (SOR) ${ }^{7}$ oraz powstałe w Wyższej Szkole Oficerskiej im. Feliksa Dzierżyńskiego Ministerstwa Spraw Wewnętrznych w Legionowie prace dyplomowe funkcjonariuszy wymienionych służb ${ }^{8}$. Zdecydowano się na analizę prac dyplomowych oficerów SB, bowiem zakładać należy, że to oni kierowali działaniami wymierzonymi w środowisko DLP i posiadali najpełniejsze rozeznanie idei leżących u podstaw DLP, jak i jej struktur, działalności oraz członków, jak i co do stosunku DLP do instytucji państwa w rzeczywistości PRL.

\section{Zagadnienia teoretyczne i hipoteza}

Postawy wobec instytucji publicznych, takich jak instytucje państwa mogą być postawami odrzucenia bądź akceptacji. Niewątpliwie a priori należy założyć istotny wpływ postaw religijnych i religijności na postawy członków DLP wobec państwa. Uczestnictwo w życiu Kościoła katolickiego oraz budowanie oddolnych ruchów tzw. przykościelnych stało w sprzeczności z systemem wartości, na którym ufundowano PRL. Statofobia oznacza takie postawy wobec państwa, które charakteryzują się lękiem bądź niechęcią lub wzgardą wobec instytucji państwa. Najpoważniejszym zaś problemem w warunkach statofobii jest brak zaufania obywateli do instytucji państwa9. W studium tym postawiono hipotezę, stanowiąca przypuszczenie, że funkcjonariusze SB postrzegali aktywistów DLP i tę organizację jako istotne zagrożenie dla bezpieczeństwa państwa i przypisywali temu środowisku postawy statofobiczne. Posta-

7 AIPN, sygn. BU 01329/662J, Sprawa Operacyjnego Rozpracowania kryptonim: Tama: Materiały dotyczace założonej w Puttusku grupy o nazwie „Duszpasterstwo Ludzi Pracy”.

8 Analizie poddano prace dyplomowe były to: AIPN, sygn. BU 001708/3659, Antypaństwowa dziatalność duszpasterstwa ludzi świata pracy $w$ rejonie gorzowskim $w$ latach 80.; AIPN, sygn. BU 001708/4037, Społeczno-religijna dziatalność duszpasterstwa ludzi pracy w Jeleniej Górze w latach 1986-1988, Legionowo 1990; AIPN, sygn. BU 001708/3565Duszpasterstwo ludzi pracy na ternie województwa wałbrzyskiego w latach 1984-1987, Legionowo 1989; AIPN, sygn. BU 001708/3155, Zagrożenia plynące $z$ działalności duszpasterstwa ludzi pracy $i$ wynikające stąd zadania dla pionu IV na przykładzie województwa bielskiego, Legionowo 1988.

9 M. Wałdoch, Statofobia jako przyczyna cofania się fali demokratyzacji, «Studia Gdańskie. Wizje i rzeczywistość» 2018, t. XV, s. 97-124. 
wiono również hipotezę pomocniczą, stanowiącą przypuszczenie, że środowisko DLP było schronieniem dla byłych działaczy NSZZ „Solidarność” i kontynuowało kierunki działalności związku, w ograniczonym zakresie, po jego delegalizacji pod sztandarami DLP. Metodami analizy była metoda leksykalna oraz metoda porównawcza ${ }^{10}$. W artykule zaprezentowano krytyczną analizę stanowiska SB - wskazując, jak postrzegano tło ideowe DLP oraz to jak prezentowano zagrożenia dla państwa komunistycznego w Polsce ze strony DLP.

\section{Podstawa ideowa DLP w oczach SB}

Ideową i programową podstawą działalności DLP była encyklika papieża Jana Pawła II Laborem exercens ${ }^{11}$ z 14 września 1981 r. Jednak na wykreowanie się tego ruchu i wsparcie oddolnych dążeń społecznych do organizowania się przy kościołach leżały także wcześniejsze encykliki papieskie. Przede wszystkim, takie jak: Humanae vitae ${ }^{12}$ Pawła VI z 22 lipca 1968 r. i Rerum novarum ${ }^{13}$ Leona XIII z 15 maja 1891 r. Dla służb bezpieczeństwa Polskiej Rzeczypospolitej Ludowej (PRL) zauważalne było odejście papieża Pawła VI na linię zachowawczą wobec marksizmu, szczególnie w adhortacji Evangelii nuntiandi ${ }^{14}$ z 8 grudnia 1975 r. Tę zachowawczą linię, a wręcz kontynuację krytyki marksizmu poprowadził

10 A. Chodubski, Wstęp do badań politologicznych, Gdańsk 2006, s. 125-126, 131.

11 Jan Paweł II, Laborem Exercens. O pracy ludzkiej (z okazji 90. rocznicy encykliki Rerum novarum) $w$ której zwraca sie do czcigodnych braci $w$ biskupstwie, do kapłanów, do rodzin zakonnych, do drogich synów i córek Kościoła oraz do wszystkich ludzi dobrej woli, Internet: http://www.vatican. va/content/john-paul-ii/pl/encyclicals/documents/hf_jp-ii_enc_14091981_laborem-exercens. html (10.11.2020).

12 Paweł VI, Humanae vitae, Internet: https://opoka.org.pl/biblioteka/W/WP/pawel_vi/ encykliki/humane.html (12.11.2020). Paweł VI pisał: „W'́ród owoców, które dojrzewają gdy prawo Boże jest gorliwie przestrzegane, niezwykle cenny jest ten, że sami małżonkowie często pragną podzielić się z innymi wynikami swoich doświadczeń. Dzięki temu w szerokich ramach powołania świeckich znajdzie się nowa i niezwykle doniosła forma apostolatu, w której równi usługują równym. Wtedy bowiem sami małżonkowie podejmują zadanie apostolskie względem innych małżonków, pełniąc rolę ich przewodników. Wśród tylu form chrześcijańskiego apostolatu ta wydaje się obecnie najpotrzebniejsza”.

13 Leon XIII, Rerum novarum, Internet: http://www.mop.pl/doc/html/encykliki/Rerum\%20 novarum.htm, dostęp: 12.11.2020. Leon XIII najdobitniej swoje stanowisko w kwestii znaczenia robotników zawarł w następującym fragmencie swojej encykliki: „[...] praca robotników jest jedynym źródłem bogactw państwa".

14 Paweł VI, Adhortacja apostolska Evangelii nuntiandi o ewangelizacji w świecie wspótczesnym, 8.12.1975, Internet: https://opoka.org.pl/biblioteka/W/WP/pawel_vi/adhortacje/evangelii_nuntiandi.html (12.11.2020). 
Jan Paweł II, którego wektory polityki Kościoła, służby w Polsce uznały za „utopijne”, między innymi dlatego, że Jan Paweł II w ich ocenie twierdził, że to „świat powinien dostosować się do Kościoła”, a nie odwrotnie. Stanowisko Jana Pawła II znalazło swoje odzwierciedlenie w encyklice Redemptor hominis ${ }^{15}$ z 4 marca 1979 r. Encyklika ta w oczach SB była świadectwem pesymizmu Jana Pawła II wobec skutków materializmu, papież wskazywał bowiem, że materializm odpowiedzialny jest za degradację godności człowieka. Kolejna encyklika Dives in misericordia ${ }^{16}$ z 30 listopada 1980 r. uważana była za wyraz chęci chrystianizacji świata i świadectwo świadomości problemów narastających nierówności społecznych w wyniku rozwoju technologicznego. Człowiek - w ujęciu papieża - stał się zdehumanizowany i żyjący amoralnie, aczkolwiek technologia miała być też dla człowieka nadzieją na zgłębianie jego istoty. Jednak dopiero w Laborem exercens ${ }^{17}$ z 14 września 1981 papież jasno wskazuje nieusuwalny konflikt i sprzeczność pomiędzy teologią a marksizmem. Komunistyczni komentatorzy relacji Kościoła wobec świata pracy uważali, że Jan Paweł II przypisuje Kościołowi katolickiemu w sposób nieuprawniony rolę podmiotu emancypującego zarówno ludzi pracy jak i pracę, kiedy to emancypacja ta była, według nich, dziełem Karola Marksa. Uważali oni, że Kościół katolicki we wcześniejszych dokumentach, szczególnie przedsoborowych, pracę postrzegał jako karę za grzechy, a dopiero w wyniku chęci sprostania wyzwaniom współczesności uznał pracę za najwyższą wartość. W oczach socjalistycznych komentatorów Kościół katolicki od czasów rewolucji październikowej do czasu II Soboru Watykańskiego (1962-1965) bardzo krytycznie, a wręcz w sposób potępiający przyjmował stanowisko wobec komunizmu i socjalizmu. Stanowisko to zmieniło się w trakcie II Soboru Watykańskiego. Kluczowe dla zmiany stanowiska Kościoła wobec komunizmu i socjalizmu oraz świata pracy miały być encykliki Jana XXIII, szczególnie Mater et Magistra ${ }^{18}$, w której papież

15 Jan Paweł II, Redemptor hominis, 4.03.1979, Internet: https://opoka.org.pl/biblioteka/W/WP/ jan_pawel_ii/encykliki/r_hominis.html (12.11.2020).

16 Jan Paweł II, Dives in misericordia, 30.11.1980, Internet: http://www.vatican.va/content/ john-paul-ii/pl/encyclicals/documents/hf_jp-ii_enc_30111980_dives-in-misericordia.html (13.11.2020).

17 Jan Paweł II, Laborem exercens, 14.11.1981, Internet: http://www.vatican.va/content/ john-paul-ii/pl/encyclicals/documents/hf_jp-ii_enc_14091981_laborem-exercens.html (13.11.2020).

18 Jan XXIII, Mater et magistra, Internet: https://opoka.org.pl/biblioteka/W/WP/jan_xxiii/ encykliki/mater_magistra_15051961.html (13.11.2020). Jan XXIII pisał w swej encyklice: „Ponadto Najwyższy Pasterz stwierdza, że tezy tak zwanych komunistów pozostają w skrajnej sprzeczności z nauką chrześcijańską". 
wyraża potrzebę godziwego wynagradzania za pracę, potępia wojnę, popiera reżimy demokratyczne oraz pozytywnie odnosi się do podróży człowieka w kosmos. Było to stanowisko całkowicie odmienne od stanowiska wcześniejszych papieży, szczególnie Piusa XI, wyrażonych w Qadragesimo anno ${ }^{19}$ z 15 maja 1931 r., które było zbieżne z linią wyznaczoną przez Leona XIII i wyrażoną w Rerum novarum, w której papież uznał pracę fizyczną za karę za grzechy, której człowiek nigdy nie uniknie. Uznał też w swej encyklice socjalizm za z gruntu zły. Twierdził, że likwidacja lub uspołecznienie własności prywatnej niesie za sobą niesprawiedliwość i gwałt. Jednocześnie uznał prywatne posiadanie dóbr przez człowieka za jego prawo naturalne ${ }^{20}$. SB dostrzegała, że Kościół katolicki po II Soborze Watykańskim dokonał znaczącego zwrotu w kierunku laikatu, który został upodmiotowiony i któremu przyznano specjalne „oddolne” działania w drodze do ewangelizacji. Wyrażone to zostało w Dokumencie o apostolstwie świeckim (Dyrektorium apostolstwa świeckich), które uchwalone zostało przez Komisję Apostolstwa Świeckich przy Konferencji Episkopatu Polski 2 czerwca 1969 r. ${ }^{21} \mathrm{~W}$ dokumencie tym uznano konieczność czynnego udziału katolików w życiu społecznym i politycznym, co stało się kamieniem węgielnym przyszłych duszpasterstw. W perspektywie SB, dokumenty te i stanowisko kościoła: „zwłaszcza w kontekście znanego już programowo antykomunizmu Kościoła, zwalczania przez kler wszelkich form ateizmu i światopoglądu marksistowskiego, zwłaszcza w warunkach Polski”22, świadczyły o tym, że Kościół może przenieść swoje stanowisko antykomunistyczne na świecki laikat, co wydatnie mogło wpłynąć na system wartości w społeczeństwie. Po delegalizacji „Solidarności” w 1981 r. DLP stały się miejscem organizacji członków byłego związku. Niemniej SB wskazywało, że przecież Jan XXIII w konstytucji Soboru Watykańskiego II Gaudium et spes ${ }^{23}$ nawoływał do tolerancji wobec osób o innych

19 Pius XI, 15.05.1931, https://opoka.org.pl/biblioteka/W/WP/pius_xi/encykliki/quadragesimo_anno_15051931.html (16.07.2021).

20 Leon XIII pisał: „Jeśli chodzi o pracę fizyczną, to nawet w stanie pierwotnej niewinności nie miał być człowiek od niej wolny. Potem zaś praca, której by wówczas dobrowolnie i z radością ducha zażywał, zmieniła się w przykrą konieczność, jako pokuta za grzech”. Leon XIII, Encyklika o kwestiach robotniczych Rerum novarum, http://www.mop.pl/doc/ html/encykliki/Rerum\%20novarum.htm (16.07.2021).

21 E. Wrona, Biuletyn teologii laikatu, «Collectanea Theologica» 1971, No 41/3, s. 157.

22 AIPN, sygn. BU 001708/3155, S. Nowak, Zagrożenie płynące z działalności Duszpasterstwa Ludzi Pracy i wynikające stąd zadania dla Pionu IV na przykładzie województwa bielskiego, praca dyplomowa, Ministerstwo Spraw Wewnętrznych Wyższa Szkoła Oficerska im. F. Dzierżyńskiego, Legionowo 1988.

23 Sobór Watykański II konstytucja Gaudium et spes, Internet: http://mamaroza.pl/biblioteczka/ sobor-watykanski-ii-konstytucja-gaudium-et-spes (2.12.2020). 
przekonaniach, a ponadto wyrażał aprobatę dla ludzi podejmujących pracę w aparacie władzy państwowej. Ponadto, zarówno z Gaudium et spes, jak i z Pacem in terris ${ }^{24}$ wypływać miało posoborowe stanowisko kościoła, zgodnie z którym „akcentuje się mocno tezę o odrębności Kościoła od państwa, jako wspólnoty politycznej”25. Choć obiektywnie rzecz ujmując, proces powstawania struktur DLP był procesem oddolnym, a Kościół przyjął na siebie funkcje organizatorskie i opiekuńcze, dając schronienie przed prześladowaniami i opresją aparatu władzy, to jednak w oczach SB DLP była świadectwem procesu zmierzającego do „[...] globalnej klerykalizacji całego społeczeństwa"26. SB w ujęciu chronologicznym, tak przedstawiało rozwój DLP: etap koncepcyjno-organizatorski (1972-1979); etap dyrektywno-wdrożeniowy (1980-1981); etap rozwijania i umacniania istniejących struktur (1982-1984); etap intensywnego przekształcania wytypowanych przyparafialnych Zespołów Synodalnych w specjalistyczne ośrodki duszpasterskie (1985-). Według SB dla Kościoła celem rozwoju DLP było związanie z Kościołem klasy robotniczej, głównie tzw. „wielkoprzemysłowej”27. Głównym hasłem pod którym działało DLP było Soli Deo et Patriae (Samemu Bogu i Ojczyźnie) 28. W skład DLP, według funkcjonariuszy SB wchodziły głównie środowiska, które korzeniami sięgały do „[...] orientacji endeckiej, chadeckiej prawicy ludowej i środowiska po AK-owskie"29. W tych właśnie środowiskach widziano tez źródło działalności politycznej w ramach DLP. Zgodnie z analizami i interpretacjami SB, członkowie DLP wykorzystywali strukturę Kościoła katolickiego w sposób zupełnie instrumentalny do rozwijania swojej aktywności ${ }^{30}$. Podnosi się tė̇ w literaturze przedmiotu pogląd zgodnie z którym „[...] Kościół musiał dostosować swą doktrynę do społecznych, politycznych i kulturowych aspiracji współczesnego człowieka [...] dopuścił inne oprócz kapitalistycznych formy ustrojowe; poddał krytyce zjawisko niesprawiedliwości społecznej, piętnował zło i nawoływał do jego

24 Jan XXIII, Pacem in terris, 11.04.1963, Internet:https://opoka.org.pl/biblioteka/W/WP/ jan_xxiii/encykliki/pacem_in_terris_11041963.html (2.12.2020). Jak pisał Jan XXIII, „Ma wreszcie prawo do otrzymywania prawdziwych informacji o wydarzeniach życia publicznego".

25 AIPN, sygn. BU 001708/3155, S. Nowak, Zagrożenie ptynace z działalności Duszpasterstwa Ludzi Pracy i wynikajace stąd zadania dla Pionu IV na przyktadzie województwa bielskiego, s. 10.

26 Ibidem, s. 29.

27 Ibidem.

28 Ibidem, s. 81.

29 AIPN, sygn. IPN BU 001708/3565, D. Pęcak, Duszpasterstwo ludzi pracy na terenie województwa wałbrzyskiego w latach 1984-1987. Praca dyplomowa, Ministerstwo Spraw Wewnętrznych Wyższa Szkoła Oficerska im. F. Dzierżyńskiego, Legionowo 1989, s. 49.

30 Ibidem, s. 49-50. 
usunięcia [...]”31. Zwraca uwagę fakt, że Kościół rzeczywiście w czasach Leona XIII, ale i jeszcze Piusa X stał na stanowiskach zachowania społeczno-politycznego status quo na świecie bez względu na położenie i niedolę robotników ${ }^{32}$.

\section{Cele DLP i forma działalności w ocenie SB}

W materiałach SB, DLP kierowało się celami nakreślonymi przez kard. H. Gulbinowicza, ten jako przewodniczący Komisji Episkopatu ds. Duszpasterstwa Ludzi Pracy, program dla DLP ujął następująco: „1. 1000 duszpasterstw na drugie tysiąclecie; 2. Tworzenie elity przywódczej, na razie do działań w duszpasterstwie; 3. Zastępowanie działań zakazanych przez władze, działaniami alternatywnymi; 4. Ujawnianie represji władz i wychodzenie z tymi faktami do społeczeństwa; 5. Udzielanie pomocy represjonowanym; 6. „Trzeba wykorzystać prawo jakie jest, żeby obudzić ze snu tych, którzy powinni doprowadzić do rzeczywistej wolności”33. SB posiadało doskonałe rozpoznanie możliwości realizacji powyższych celów przez DLP. W swoich wewnętrznych analizach wskazywało, że dla tak postawionych kierunków działalności DLP będzie prowadziło uniwersytety robotnicze, które miały być odpowiedzią na tzw. „latające uniwersytety”, prowadzone przez Komitet Obrony Robotników (KOR). Członków DLP uczono technik fotografowania, druku, oraz nagrywania w formie audio i video. Ponadto, uczono w ramach DLP w jaki sposób redagować i wydawać czasopisma. SB zauważał też dużą aktywność rekrutacyjną, szczególnie poprzez organizowanie nabożeństw w danych intencjach (za ojczyznę, itd.). W ramach DLP, według SB próbowano reaktywować zalążki organizacji przedwojennych, takich jak Stowarzyszenie Katolickiej Młodzieży Akademickiej „Odrodzenie” na terenie ówczesnego województwa leszczyńskiego. Poza tym, DLP organizowała pomoc materialną i prawną dla osób skazanych za działalność polityczną i dla internowanych, w tym dla rodzin takich aktywistów ${ }^{34}$. Jedną z najistotniejszych uwag, wskazujących wage „problemu” jaki Służba Bezpieczeństwa dostrzegała w DLP, była następująca konstatacja jednego z dyplomantów WSO im. Feliksa Dzierźyńskiego w Legio-

31 K. Kąkol, Kościót w PRL. Elementy ewolucji doktryny, Warszawa 1985, s. 13.

32 Ibidem, s. 19-20.

33 AIPN, sygn. BU 001708/3155, S. Nowak, Zagrożenie ptynace z działalności Duszpasterstwa Ludzi

Pracy i wynikające stąd zadania dla Pionu IV na przyktadzie województwa bielskiego, s. 33.

34 Ibidem, s. 34. 
nowie: „Polityczny wymiar działalności i jej kierunki określa znaczący ilościowy udział byłych aktywistów NSZZ »Solidarność i dlatego nie można wykluczyć, że występuje nakładanie się, czy też zazębianie działalności podziemia i DLP”35. Dostrzegano w szeregach tajnej milicji, że DLP jest środowiskiem, na bazie którego mogą w przyszłości rozkwitnąć związki zawodowe w nurcie chrześcijańskim. Świadczyć o tym miał, między innymi, tylko symboliczny udział osób duchownych w pracach DLP, bowiem kapłani poza odprawianiem Mszy Świętych i ewentualnie dawaniem odczytów nt. nauki Kościoła katolickiego nie włączali się w pracę DLP i pozwalali na dużą samodzielność członków tej organizacji, pomimo tego, że korzystano z infrastruktury kościelnej. Uważano, że wysokie zaufanie Kościoła do liderów świeckich DLP wynikało w dużej mierze z zasady samorządności panującej w DLP oraz z zaufania wobec już wypróbowanych aktywistów, którym ufali przede wszystkim proboszczowie danych parafii, przy których organizowały się i funkcjonowały DLP ${ }^{36}$. W przygotowanych dokumentach dla DLP Kuria Warszawska, wskazywała na konieczność głoszenia referatów wśród członków DLP, szczególnie o tematyce historycznej i społecznej. Ponadto Kościół postanowił wspomóc rodziny członków DLP, poprzez organizację kolonii dla dzieci37. W referatach i wykładach, zaproszeni przez DLP goście mówili między innymi o prawdzie historycznej dotyczącej okupacji sowieckiej; o prawach i obowiązkach obywateli; w ujęciu krytycznym omawiali marksizm; wskazywali na serwilizm mass mediów wobec władzy ludowej; głosili potrzebę dążenia do realizacji idei wolności poprzez faktyczną i realną działalność polityczną oraz walkę. Ponadto dyskutowano kwestie ochrony środowiska i związane z nią zagadnienia, takie jak nielegalne składowanie na terenie Polski odpadów radioaktywnych w rejonie Międzyrzeckim, krytykując także zamysły budowy elektrowni jądrowej w Klempiczu i wskazując na liczne zagrożenia z tym związane. Prelegenci DLP określali system komunistyczny jako legalizujący się na bazie zakłamania i krętactw. Funkcjonariuszy reżimu komunistycznego nazywano posłusznymi „automatami”, bowiem zaprzedali swój rozum i serce dla zbrodniczego systemu. Wskazywano też na zgubne skutki reżimu komunistycznego, który w sferze duchowej prowadził do ateizacji życia. Omawiano także problematykę międzynarodowego zadłużenia Polski, które postrzegano w kręgach DLP jako godzące w ideę suwerenności

35 Ibidem.

36 Ibidem, s. 40, 42-43.

37 Ibidem, s. 38. 
państwa. Krytykowano gospodarkę socjalistyczną i podkreślano wartość kapitalizmu i jego znaczenie dla szybkiego postępu ludzkościs8.

Podstawowym obszarem działalności danego DLP była parafia, lub dekanat dla mniejszych skupisk ludzkich. Formalnie, poza proboszczem, pieczę nad DLP mógł pełnić wikariusz posiadający odpowiednią wiedzę w zakresie katolickiej nauki społecznej oraz o wyraźnie patriotycznej postawie. Zakładano, że każda komórka DLP powinna obejmować od 10-20 zaangażowanych i gotowych do poświęcenia się w imię „Boga i Ojczyzny” osób, głównie ze środowisk robotniczych. Dla podbudowy działalności i wiarygodności DLP jej działacze mieli wskazywać, że ich działalność jest zgodna z dokumentami II Soboru Watykańskiego oraz z nauczaniem papieża Jana Pawła II. Ponadto, działalność DLP postrzegano także jako antidotum na działalność organizacji „katolików świeckich”, takich jak Stowarzyszenie „Pax”, Chrześcijańskie Stowarzyszenie Społeczne (ChSS) i Polski Związek Katolicko-Społeczny (PZKS). Wewnętrzna organizacja DLP była elastyczna i dostosowana do warunków zewnętrznych i realiów danej parafii. Każde DLP poza kuratelą proboszcza lub wyznaczonego przez niego wikariusza powinno było posiadać seniora będącego przewodniczącym zarządu DLP oraz wiceseniora jako wiceprzewodniczącego DLP, każdy zarząd DLP składał się z 5 osób, a najwyższym organem było Zgromadzenie Ogólne Członków DLP. Każde DLP mogło wyodrębniać zespoły, np. ds. współpracy z młodzieżą, winno było też pomagać parafii w pozyskiwaniu prelegentów, szczególnie naukowców z określonych dyscyplin nauki. Członkostwo w organizacji było otwarte dla wszystkich ludzi pracy, nie zamykało się także na młodzież, jeśli ta była dojrzała moralnie. W odniesieniu aksjologicznym, osią działalności był polski patriotyzm ${ }^{39}$. Natomiast w oczach funkcjonariuszy SB „[...] występowanie w obronie ludzi represjonowanych oraz ujawnienie wszelkich nieprawidłowości popełnionych przez organa władzy i administracji państwowej" ${ }^{40}$, to były główne cele na których koncentrowało się DLP. Funkcjonariusze zauważali, że w ich opinii, Kościół poprzez DLP wiązał się z „ekstremą polityczną” 41 z „Solidarności” i udzielał parasola

38 AIPN, sygn. IPN BU 001708/3659, Z. Wołczecki, Antypaństwowa działalność duszpasterstwa ludzi świata pracy $w$ rejonie gorzowskim $w$ latach 80-tych, s. 40-45.

39 AIPN, sygn. BU 001708/3155, S. Nowak, Zagrożenie plynące z dziatalności Duszpasterstwa Ludzi Pracy i wynikające stąd zadania dla Pionu IV na przykładzie województwa bielskiego, s. 81-85.

40 AIPN, sygn. IPN BU 001708/3565, D. Pęcak, Duszpasterstwo ludzi pracy na terenie województwa watbrzyskiego w latach 1984-1987. Praca dyplomowa, Ministerstwo Spraw Wewnętrznych Wyższa Szkoła Oficerska im. F. Dzierżyńskiego, Legionowo 1989, s. 52.

41 Ibidem, s. 55. 
oraz schronienia dla dalszej działalności opozycyjnejej, po delegalizacji związku. Sytuację w której Kościół udzielał schronienia, z państwowego punktu widzenia ekstremie politycznej, dostrzegał także kierownik Urzędu do Spraw Wyznań Kazimierz Kąkol, który taką postawę duchowieństwa w liście do Prymasa Polski nazwał działalnością „szkodliwą dla narodu”. Szczególnie krytykując ideę „latającego uniwersytetu”, którą uważał jedynie na zasadzoną na myśli o szerzeniu zachowań antysocjalistycznych. K. Kąkol podkreślił także, że: „Państwo jest tą formą organizacji, która najpełniej służy zabezpieczeniu interesów narodu"43.

\section{Zagrożenia dla państwa ze strony DLP w analizach SB}

Działalność DLP była odbierana jako realne zagrożenie dla państwa i przyjętego ładu politycznego. Szczególnie dostrzegano możliwość zagrożeń w sferze ideologicznej oraz społeczno-politycznej, ale także w sferze gospodarczej, naukowej i kulturowej poprzez podważanie „osiągnięć” PRL. Uważano, że samo zaangażowanie świeckich w działalność Kościoła spowoduje, poprzez wpływ katolickiej nauki społecznej, utratę zaufania do państwa. Uważano, że Kościół działa celowo, przygotowując kadry przyszłej elity politycznej, w tym dla utworzenia, jak się spodziewano, partii chadeckiej ${ }^{44}$. Ocena SB wiązała się z dostrzeganiem zagrożeń płynących z szeroko zakrojonej działalności politycznej DLP. Twierdzono, że prowadzą one do nasilania się konfliktów społecznych oraz pogłębiania kryzysu społeczno-politycznego, choć nie wskazywano na poparcie tych twierdzeń żadnych faktów. Niemniej faktem było, że dzięki działalności DLP, Kościół coraz silniej wpisywał się w rolę nie tylko mediatora pomiędzy opozycją demokratyczną i państwem komunistycznym, ale także i obrońcy społeczeństwa. Na krytyczną ocenę DLP wpływało organizowanie mszy świętych w intencji np. uwolnienia więźniów politycznych, ale i organizowanie odczytów i prelekcji na temat historii Polski, gospodarki, polityki, które głosili często ludzie o poglądach

42 AIPN, sygn. IPN BU 001708/3659, Z. Wołczecki, Antypaństwowa działalność duszpasterstwa ludzi świata pracy $w$ rejonie gorzowskim $w$ latach 80-tych, Ministerstwo Spraw Wewnętrznych Wyższa Szkoła Oficerska im. F. Dzierżyńskiego, Legionowo 1989, s. 3.

43 K. Kakol, Kościót w PRL..., s. 291-294.

44 AIPN, sygn. BU 001708/3155, S. Nowak, Zagrożenie plynace z działalności Duszpasterstwa Ludzi Pracy $i$ wynikające stąd zadania dla Pionu IV na przykładzie województwa bielskiego, s. 57-58. Obawy te były bezzasadne, jak się okazało nie tylko w PRL, ale i w III RP ugrupowania chrześcijańskie na scenie politycznej w Polsce nigdy nie uzyskały oficjalnego wsparcia Kościoła katolickiego, ani nie stanowiły jego politycznego ramienia w Polsce. 
antysystemowych. Ponadto organizacja wszelkich rekolekcji z udziałem młodzieży i młodych robotników; Tygodni Kultury Chrześcijańskiej, udzielanie się w wydawnictwach podziemnych dyskredytujących PZPR i państwo, organizowanie pomocy materialnej da internowanych i więzionych za przekonania polityczne, udział w rozdzielaniu darów pomocy charytatywnej z zagranicy, organizowanie pomocy prawnej, wykorzystanie mszy świętych do wieców o charakterze antypaństwowym i antysocjalistycznym, inspirowanie zakładów pracy do strajków, akcji protestacyjnych oraz petycji ${ }^{45}$. Zauważano także, że Kościół we współpracy z DLP stosuje w swoich akcjach najnowsze zdobycze techniki, wywołując tym duże zainteresowanie aktywistów. Uważano, że dzięki takim działaniom, Kościół umacnia swoją pozycję kosztem deprecjacji znaczenia państwa w życiu obywateli. Jednocześnie zdawano sobie sprawę, że u podstaw popularności DLP leżało niezaspokojenie potrzeb społecznych przez państwo, słabość kadr naukowych i dydaktycznych w szkolnictwie oraz brak środków finansowych na imprezy kształtujące „świadomość socjalistyczną"46.

Przykładem działań SB wobec DLP była Sprawa Operacyjnego Rozpracowania „TAMA”, którą wszczęto już u schyłku systemu, 1 marca 1988 r. wobec środowiska DLP w Pułtusku, której powstanie określono jako „[...] nieoficjalnej grupy klerykalnoprosolidarnościowej” ${ }^{47}$. Operacja służb zakończyła się sukcesem, bowiem doprowadzono do dezintegracji środowiska ${ }^{48}$. Rozbita grupa składała się z 5 osób o „korzeniach inteligenckich” którzy powołali DLP przy parafii Św. Mateusza w Pułtusku. Miejscem spotkań była sala katechetyczna. Według SB w trakcie spotkań dyskutowano aktualne problemy społeczno-polityczne i gospodarcze. Ponadto, wskazywano, że: „[n]iektórzy z uczestników tych dyskusji wskazują w swoich wypowiedziach na potrzebę poszukiwania nowych form tzw. niezależnego udziału obywateli w życiu publicznym kraju poprzez budowanie struktur tzw. niezależnego społeczeństwa” ${ }^{49}$, ponadto zauważano, że DLP w Pułtusku będzie dążyło do „niezależnej oświaty i współ-

45 Ibidem, s. 58-60.

46 Ibidem, s. 71.

47 AIPN, sygn. BU 01329/662J, Sprawa Operacyjnego Rozpracowania kryptonim: Tama: Materiały dotyczace założonej $w$ Puttusku grupy o nazwie „Duszpasterstwo Ludzi Pracy”. Notatka Informacyjna, 25.10.1990, s. 1.

48 Ibidem.

49 AIPN, sygn. BU 01329/662J, Sprawa Operacyjnego Rozpracowania kryptonim: Tama: Materiaty dotyczqce założonej w Puttusku grupy o nazwie „Duszpasterstwo Ludzi Pracy”. Wniosek o wszczęcie sprawy operacyjnego sprawdzania krypt. „TAMA”, Ciechanów 15.01.1988, s. 1-2. 
pracy z nielegalnymi oficynami wydawniczymi”50. Jednocześnie DLP uznano za organizację nielegalną ${ }^{51}$. Informacje nt. działalności i członków DLP, w tym ich motywacji oraz celów, SB pozyskiwała od TW52. Według ocen wałbrzyskiej SB, działalność DLP dynamicznie ewoluowała od form znanych grupom przykościelnym i wokół aktywności religijnej ku działaniom „wrogim” 53 .

\section{Formy przeciwdziałania DLP}

DLP podlegała operacyjnie pod Wydział IV MSW, który opracowywał metody neutralizacji tej organizacji jak i jej członków. Do form działalności mających powstrzymywać DLP, należało prowadzenie Teczek Ewidencji Operacyjnej na Księdza (TEOK), które prowadzone były od czasu wstąpienia do Seminarium Duchownego do czasu zgonu danego księdza. Nadto prowadzono Teczkę Operacyjną na Parafię (TOP); Teczkę Operacyjną na Biskupa (TOB); Kwestionariusze Ewidencyjne na osoby świeckie prowadzące działalność antysystemową (tzw. wrogą); Sprawy Operacyjnego Sprawdzania (SOS) prowadzone na analizę zjawisk; Sprawy Operacyjnego Rozpracowywania (SOR) dla rozpoznania metod oraz zakresu tzw. wrogiej działalności. Do metod pracy operacyjnej wykorzystywanej przez Wydział IV wobec DLP, zaliczano: analizę operacyjną, rozmowy operacyjne, wywiad ustaleniowy, obserwację, inwigilację, sprawdzenie operacyjne, inspirację operacyjną, dezinformację i dezintegrację operacyjną i rozpracowanie operacyjne. Ponadto dokonywano zabezpieczeń mszy świętych i innych uroczystości kościelnych, w tym pielgrzymek. Wskazano także, że: „W celu zapobiegania powstawaniu zagrożeń, neutralizowaniu i likwidacji ewentualnych skutków działań Kościoła na odcinku DLP, Dep. IV SB MSW prowadzi pracę operacyjną w środowisku kleru i świeckich członków duszpasterstwa" ${ }^{4}$. Wytyczne

50 AIPN, sygn. BU 01329/662J, Sprawa Operacyjnego Rozpracowania kryptonim: Tama: Materiały dotyczace zatożonej w Puttusku grupy o nazwie „Duszpasterstwo Ludzi Pracy”. Wniosek o wszczęcie sprawy operacyjnego rozpracowania kryptonim „TAMA”, Ciechanów 1.03.1988, s. 1-2.

51 Ibidem, s. 3.

52 AIPN, sygn. BU 01329/662J, Sprawa Operacyjnego Rozpracowania kryptonim: Tama: Materiaty dotyczace założonej w Pultusku grupy o nazwie „Duszpasterstwo Ludzi Pracy”. Wniosek o wszczęcie sprawy operacyjnego sprawdzania krypt. „TAMA”, Ciechanów 15.01.1988, s. 2.

53 AIPN, sygn. IPN BU 001708/3565, D. Pęcak, Duszpasterstwo ludzi pracy na terenie województwa watbrzyskiego w latach 1984-1987, s. 58.

54 AIPN, sygn. BU 001708/3155, S. Nowak, Zagrożenie ptynące z działalności Duszpasterstwa Ludzi Pracy i wynikające stąd zadania dla Pionu IV na przykładzie województwa bielskiego, praca dyplo- 
Dyrektora Departamentu IV MSW z dn. 15.06.1973 w sprawie form i metod działania operacyjnego Dep. IV i jego odpowiedników w terenie, wskazywały, że dozwolone było dla funkcjonariuszy SB stosowanie metod i środków, które nie były konieczne i przydatne „na innych odcinkach i w realizowaniu innych zdań”. Natomiast do podstawowych form pracy operacyjnej wobec DLP należały Sprawy Obiektowe (SO), które realizowane były przy pomocy Tajnych Współpracowników (TW), często bardzo ściśle związanych ze środowiskami DLP lub będących członkami DLP. Zgodne było to z Instrukcją nr 001/77 Dyr. Dep. IV MSW z dn. 15 marca 1977 r. ${ }^{55}$ Ponadto 30 kwietnia 1985 r. wiceminister MSW skierował do zastępców szefów WSW ds. bezpieczeństwa dyspozycję w sprawie przyporządkowania pracy operacyjnej poszczególnych pionów MSW wobec DLP. I tak Wydział IV Departamentu IV MSW prowadził sprawy obiektowo-kontrolne na DLP, Duszpasterstwa Wspólnoty Rolników, Duszpasterstwo Młodzieżowe, Duszpasterstwo Akademickie oraz Duszpasterstwo Nauczycieli ${ }^{56}$. SB poprzez TW uczestniczyło w imprezach organizowanych przez DLP oraz inwigilowało kontakty organizacji, w tym w wydawnictwach. Dążono także do rozpoznania działań, które mogły przynieść negatywne skutki dla państwa i PZPR w sferze ideologicznej, a które podejmowane były przez DLP. Prowadzono także rozpoznanie liderów DLP oraz nowych członków, próbując określić ich sympatie i postawy polityczne, w tym ich ewentualne zaangażowanie w działalność wroga państwu, poszukiwano poprzez nich także kontaktów z podziemnymi strukturami NSZZ „Solidarność”. SB w parafiach przy których organizowało się DLP, prowadziło rozmowy profilaktyczne z proboszczami parafii oraz członkami kierownictwa DLP. Nadto SB przygotowywała anonimy na działaczy DLP, które przekazywane były kuriom biskupim, aby dyskredytować poszczególnych aktywistów jak i cały ruch. Z drugiej strony tworzono nacisk na biskupów, aby ci możliwie mocno ograniczali działalność masową DLP, w tym chodziło minimalizację działalności antysystemowej związanej z DLP, takiej jak udział księży, którzy głosili kazania godzące w podstawy ustroju. Niezwykle istotnym aspektem działań SB wobec DLP były działania dezorganizacyjne i inspiracyjne, w działaniach tych celem było wywołanie swarów na tle roli i funkcji osób duchownych w DLP; spowodowanie rozdźwięków

mowa, Ministerstwo Spraw Wewnętrznych Wyższa Szkoła Oficerska im. F. Dzierżyńskiego, Legionowo 1988, s. 64.

55 Ibidem, s. 65-66.

56 AIPN, sygn. IPN BU 001708/3565, D. Pęcak, Duszpasterstwo ludzi pracy na terenie województwa watbrzyskiego w latach 1984-1987, s. 50-51. 
pomiędzy członkami organizacji na tle podejmowanej tematyki i form aktywności - występowanie poprzez TW z kontrpropozycjami. Dążono na przykład do dyskredytacji prelegentów występujących z odczytami nt. historii i polityki oraz do przekierowania uwagi i energii aktywistów ze spraw społeczno-politycznych i gospodarczych na wymiar religijny, duchowy. Za główny cel stawiano sobie dezintegrację środowiska DLP w związku z zagrożeniem jakie niosło ono dla reżimu komunistycznego w Polsce ${ }^{57}$. Ponadto wskazywano, że należy rozeznać podstawy prawne działalność DLP, gdyż w 1952 r. ograniczono działalność stowarzyszeń katolickich w Polsce, zamierzano manipulować starszymi wiekiem księżmi, aby zniechęcać ich do dodatkowej pracy z DLP, postulowano gromadzenie danych o tzw. „kościołach otwartych” wokół których bardzo prężnie funkcjonowały zalążki nowych ruchów społecznych ${ }^{58}$.

\section{Zakończenie}

W toku prowadzonego badania potwierdzono hipotezę, stanowiącą przypuszczenie, że funkcjonariusze SB postrzegali aktywistów DLP i tę organizacje jako istotne zagrożenie dla bezpieczeństwa państwa i przypisywali temu środowisku postawy statofobiczne. Potwierdzono także hipotezę pomocnicza, stanowiącą przypuszczenie, że środowisko DLP było schronieniem dla byłych działaczy NSZZ „Solidarność” i kontynuowało kierunki działalności związku, w ograniczonym zakresie, po jego delegalizacji pod sztandarami DLP.

Poza tym należy uznać, iż we wszystkich analizowanych przypadkach, SB stwierdzała, iż liderami i częstokroć organizatorami DLP w parafiach byli niedawni liderzy NSZZ „Solidarność”. Dodatkowo zauważano, że o działalności DLP informowano w wydawnictwach nielegalnych ${ }^{59}$.

Środowisko DLP pozostaje nadal słabo zbadane, a jego waga dla organizacji opozycji demokratycznej po formalnej delegalizacji NSZZ „Solidarność” wydaje się być niedostrzegalna przez badaczy tego okresu, stąd należy postulować pogłębianie badań nad DLP i towarzyszącymi mu zdarzeniami i zjawiskami. Ze zgromadzonego i analizowanego materiału

57 AIPN, sygn. BU 001708/3155, S. Nowak, Zagrożenie plynące z działalności Duszpasterstwa Ludzi Pracy i wynikające stąd zadania dla Pionu IV na przykładzie województwa bielskiego, s. 63-64.

58 AIPN, sygn. IPN BU 001708/3659, Z. Wołczecki, Antypaństwowa działalność duszpasterstwa ludzi świata pracy $w$ rejonie gorzowskim $w$ latach 80-tych, s. 49-50.

59 AIPN, sygn. IPN BU 001708/3659, Z. Wołczecki, Antypaństwowa działalność duszpasterstwa ludzi świata pracy $w$ rejonie gorzowskim $w$ latach 80-tych, s. 37. 
wynika, że SB prowadziła sprawy operacyjne przeciwko DLP i jej członkom do końca upadku reżimu komunistycznego w Polsce. Uznać można, że funkcjonowanie DLP było niezwykle istotnym elementem przetrwania dla sieci kontaktów byłych członków NSZZ „Solidarność, którzy w rzeczywistości stanu wojennego i po jego zniesieniu nie mieli żadnych innych możliwości utrzymywania kontaktu i wymiany myśli. Stąd zasadnym jest twierdzić, że bez DLP, środowiska opozycji demokratycznej w Polsce byłyby, prawdopodobnie, niezdolne do wywierania skutecznej presji na system komunistyczny, co w efekcie doprowadziło do załamania się tego systemu i jego upadku. W świetle analizowanych dokumentów potwierdzają się też ustalenia Jana Żaryna, który uznał Kościół w okresie stanu wojennego i później za azyl dla wielu działaczy i aktywistów politycznych bez względu na ich związki z Kościołem. Natomiast środowiska duszpasterskie, w tym DLP, za ośrodki niezależnej myśli społecznej oraz tworzacej się alternatywnej kultury ${ }^{60}$.

\section{Bibliografia}

Boryszewski P., Duszpasterstwa Ludzi Pracy w latach 1973-1990, Warszawa 1995.

Chodubski A., Wstęp do badań politologicznych, Gdańsk 2006.

Łatka R., Episkopat Polski wobec stosunków państwo-kościót i rzeczywistości spoteczno-politycznej PRL 1970-1989, Warszawa 2019.

Łatka R., Komuniści i Kościót w Polsce „ludowej” w perspektywie centralnej i krakowskiej, Radzymin-Warszawa 2016.

Kąkol K., Kościót w PRL. Elementy rewolucji doktryny, Warszawa 1985.

Kowal P., Koniec systemu władzy. Polityka ekipy gen. Wojciecha Jaruzelskiego w latach 1986-1989, Warszawa 2015.

Wałdoch M., Duszpasterstwo Ludzi Pracy w Chojnicach: geneza, idee, struktura, ludzie i działalność polityczna (1982-1989), «Zeszyty Chojnickie» 2017, nr 33.

Wałdoch M., Statofobia jako przyczyna cofania sięfali demokratyzacji, «Studia Gdańskie. Wizje i rzeczywistość» 2018, t. XV.

Wrona E., Biuletyn teologii laikatu, «Collectanea Theologica» 1971, 41/3.

Żaryn J., Kościót w PRL, Warszawa 2004.

60 J. Żaryn, Kościót w PRL, Warszawa 2004, s. 143-149. 